\title{
Merging academic research and industry requirements for innovative construction management practices in Sri Lanka: A study on critical success factors
}

Chandanie Hadiwattege ${ }^{\mathrm{a}}$, Sepani Senaratne ${ }^{\mathrm{b}}$, Y.G. Sandanayake ${ }^{\mathrm{a}}$ and Nirodha Fernando ${ }^{c}$,

${ }^{a}$ Department of Building Economics, University of Moratuwa, Moratuwa, Sri Lanka; ${ }^{b}$ School of Built Environment, Western Sydney University, Sydney, Australia; ${ }^{c}$ School of the Built

Environment, University of Salford, Manchester, UK

The application of a 'knowledge-based economy', which is a mainstream theory in many sectors, is rarely visible in the construction industry, especially in developing countries. Accordingly, the negative consequence of weak academic-industry interactions has created many hindrances to the development of the construction sector. Hence, it is essential to lead the construction industry towards innovations through research-informed management practices, which urges for strong academic-industry assimilation. Hence, this study aimed to investigate the Critical Success Factors (CSFs) for research-driven construction management innovations. A comprehensive literature review was carried out first and empirical data were collected from the Sri Lankan context using the mixed-research approach informed by a pragmatist philosophical stance. The perspectives of academia and industry were deductively obtained through questionnaires and inductively explored through semi-structured interviews. The findings were accumulated to a model and validated externally through expert interviews. The Model of CSFs for Research-driven Innovations (MRI) in construction management practices displays the CSFs stage-wise, concerning the actionable stakeholders. The research confirms the academic research's potential to foster innovations in construction management practices if righteously initiated inside the innovation space, executed properly, and disseminated strategically.

Keywords: academic research; industry requirements; construction management practice; Critical Success Factors; innovation; research knowledge dissemination and utilization.

\section{Introduction}

Communicating research outcomes lies at the heart of academic endeavors leading to improved knowledge in the related industries whilst realizing further research directions (Schiuma, 2012). This urges universities to equip with specialist staff; identify and manage knowledge resources with business potential; take new ideas to market; acquire resources; and obtain the 
interest of adequate buyers (Carter, 2013). Complementarily, the industries have begun to treat public knowledge as a strategic resource (Ivanova \& Leydesdorff, 2014). Many companies developing an open innovation approach to Research and Development (R\&D) combining inhouse and external resources are aiming to maximize the economic value of the intellectual property (Ivanova \& Leydesdorff, 2014).

Although MacLeod (2010) claims that the standard of innovations in the construction industry is good, major construction industry reviews, especially in developed countries, especially in developed countries have identified the need for continuous performance improvement over the time (Noktehdan, Shahbazpour, Zare, \& Wilkinson, 2019; Ellie, Andrew, \& Michael, 2012; Egan, 1998). Brandon has called for a 'paradigm shift' in the research in 1982, which was one of the first public pronouncements on the need for changing how construction processes are researched and practiced. Yet, in the years since Brandon's call, innovations and 'new paradigms' have appeared, but the questions remain, as for how far it has come, how much the knowledge has been developed, and to what extent the methods have improved to benefit construction industry (Alwan, Jones, \& Holgate, 2016; Fellows, 2010; Brandon, 2009). Ellie et al. (2012) propose that academia and industry should develop a better mutual understanding of innovative project delivery in the construction industry. Considering the background, it is apparent that the academic research assistance for construction industry innovations is inferior, while academic research is a key influencer in directing industries towards innovations.

Although there are important researches carried out by academia, disseminating knowledge to the construction industry is challenging. Irrespective of the opportunities created for each partner, conflicts of interest may arise first analytically and then related to the problems of economic productivity, wealth retention, and knowledge growth (Godin \& Gingras 2000). Therefore, changes are required to the systems and the relationships among the stakeholders of innovation, at organizational, local, regional, national, and multinational levels (Etzkowitz, 2011).

Given the background, this research hypothesizes that there are pre-requisites for establishing academic-industry research links. Accordingly, the research question is established as "what are the Critical Success Factors (CSFs) of merging academic research and industry development requirements in creating an innovative construction management practice?". Accordingly, this research investigated the CSFs of fostering research-driven management innovations, particularly to the Sri Lankan construction industry.

\section{Literature Review}

This study first reviewed the existing literature to abstract potential success factors of researchdriven innovations. Next, a theoretical structure was conceptualized to include the essential stages and respective stakeholders' roles. This section, therefore, presents the literature on two knowledge domains, i.e. (i) Success factors for merging academic research and construction industry development requirements, and (ii) Theories of research-informed innovative development. 
Success Factors of Merging Academic Research and Construction Industry Development Requirements

The potential success factors were abstracted under three major areas, i.e. (i) success factors for academia, (ii) success factors for the construction industry, and (iii) success factors to be practiced collaboratively, following the work of Alker (2008). Potential success factors for academia were classified into three sub-categories based on the stages of the research process i.e. (i) initiation, (ii) execution, and (iii) dissemination. Moreover, potential success factors for the construction industry were abstracted in two sub-categories based on the level of operation, i.e. (i) at the individual organizations/practitioners level, and (ii) at the industry level. Individual academic and industrial potential success factors are presented in Tables 1 and 2, respectively.

Table 1. Success Factors for Academia in Research Knowledge Dissemination - Research Initiation and Research Execution

\begin{tabular}{|c|c|c|c|c|c|}
\hline $\begin{array}{l}\text { Rank } \\
\text { Code }\end{array}$ & $\begin{array}{l}\text { Success factors - Research } \\
\text { Initiation }\end{array}$ & Code & $\begin{array}{l}\text { Success factors - Research } \\
\text { Execution }\end{array}$ & Code & $\begin{array}{l}\text { Success factors - Research } \\
\text { Dissemination }\end{array}$ \\
\hline 5 WI1 & $\begin{array}{l}\text { Create new knowledge linked to } \\
\text { development goals [1] }\end{array}$ & $6 \mathrm{WP1}$ & Assure research quality [10] & 7 WD1 & $\begin{array}{l}\text { Multiple dissemination } \\
\text { techniques [14] }\end{array}$ \\
\hline 4 WI2 & $\begin{array}{l}\text { Be biased towards applied } \\
\text { research [2] }\end{array}$ & 5 WP2 & $\begin{array}{l}\text { Balance teach-ability, complexity, } \\
\text { and specificity of research [11] }\end{array}$ & $4 \mathrm{WD} 2$ & $\begin{array}{l}\text { Specialist staff with } \\
\text { business potential to }\end{array}$ \\
\hline 8 WI3 & $\begin{array}{l}\text { Undertake conceptually } \\
\text { researchable to gradually } \\
\text { penetrate to the industry [2] }\end{array}$ & 4 WP3 & $\begin{array}{l}\text { Execute research methodologically } \\
{[12]}\end{array}$ & & $\begin{array}{l}\text { manage knowledge } \\
\text { resources [4] }\end{array}$ \\
\hline $10 \mathrm{WI} 4$ & $\begin{array}{l}\text { Prioritize research in academic } \\
\text { job description [3] }\end{array}$ & 8 WP4 & Summarise research [9] & 3 WD3 & $\begin{array}{l}\text { Communicate higher-level } \\
\text { research outcome to a }\end{array}$ \\
\hline 11 WI5 & $\begin{array}{l}\text { Research related to the teaching } \\
\text { discipline of the academic [4] }\end{array}$ & 7 WP5 & $\begin{array}{l}\text { Affiliation authorized thanking } \\
\text { letters to study participants [9] }\end{array}$ & & broader community [9] \\
\hline 6 WI6 & $\begin{array}{l}\text { Align research interest with } \\
\text { industry needs [5] }\end{array}$ & 9 WP6 & Newsletters to study participants [9] & $1 \mathrm{WD} 4$ & $\begin{array}{l}\text { Ensure the availability to } \\
\text { the target audience [15] }\end{array}$ \\
\hline $1 \mathrm{WI7}$ & $\begin{array}{l}\text { Abstract research ideas from the } \\
\text { industry [6] }\end{array}$ & $1 \mathrm{WP7}$ & $\begin{array}{l}\text { Value creation through the research } \\
\text { process [13] }\end{array}$ & $\begin{array}{l}\mathbf{6} \text { WD5 } \\
\mathbf{2} \text { WD6 }\end{array}$ & $\begin{array}{l}\text { Allow feedback from the } \\
\text { audiences [12] }\end{array}$ \\
\hline \multirow[t]{2}{*}{$\begin{array}{l}9 \text { WI8 } \\
\text { 2 WI9 } \\
7 \text { WI10 } \\
\text { 3 WI11 }\end{array}$} & $\begin{array}{l}\text { Focus on both global challenges } \\
\text { and individual industries [7] } \\
\text { Establish networks of expertise } \\
\text { [8] }\end{array}$ & $\begin{array}{l}3 \text { WP8 } \\
2 \text { WP9 }\end{array}$ & \multirow[t]{2}{*}{$\begin{array}{l}\text { Reduce complications and } \\
\text { administrative burdens of research } \\
\text { funding [6] } \\
\text { Establish academic research } \\
\text { development centers [2] }\end{array}$} & \multirow[t]{2}{*}{5 WD7 } & $\begin{array}{l}\text { Tailor research findings } \\
\text { enabling use in } \\
\text { policymaking [16] } \\
\text { Present research outcome as } \\
\text { a beneficial solution [9] }\end{array}$ \\
\hline & $\begin{array}{l}\text { Bring an end-user perspective to } \\
\text { the knowledge dissemination } \\
\text { plans [6] } \\
\text { Dissemination plans in initial } \\
\text { academic research proposals [9] }\end{array}$ & & & & \\
\hline $\begin{array}{l}\text { [1] Kas } \\
\text { Bigelov } \\
\text { [13] Le }\end{array}$ & $\begin{array}{l}\text { 009; [2] Puddicombe \& Johnson, } \\
\text { bo, \& Baker, 2016; [7] Egbu, } 200 \\
\text { onn, 2007; [14] Meek et al., } 2009\end{array}$ & ; [3] E & $\begin{array}{l}\text { \& Michael, 2012; [4] Amaratunga } \\
\text { loñez \& Serrat, 2009; [10] OECD, } \\
\text { RD Direct, } 2009\end{array}$ & enaratr & $\begin{array}{l}009 ;[5] \text { B rown, 2005; [6] } \\
\text { sers, 2011; [12] Alker, 2008; }\end{array}$ \\
\hline
\end{tabular}

Table 2. Success Factors for Industry in Research Knowledge Utilisation

\begin{tabular}{llll}
\hline $\begin{array}{l}\text { Rank } \\
\text { Code }\end{array}$ & $\begin{array}{l}\text { Success factors - To be implemented as an } \\
\text { Industry }\end{array}$ & $\begin{array}{l}\text { Rank } \\
\text { Code }\end{array}$ & $\begin{array}{l}\text { Success factors - To be implemented as } \\
\text { Individual Organisations/Practitioners }\end{array}$ \\
\hline $\mathbf{2}$ WB1 & $\begin{array}{l}\text { Develop open innovation approaches to } \\
\text { R\&D [3] }\end{array}$ & $\begin{array}{l}\mathbf{6} \\
\text { WW1 }\end{array}$ & $\begin{array}{l}\text { Change the internal dynamics of construction } \\
\text { organizations to be able to respond to change [3] }\end{array}$ \\
\hline
\end{tabular}




\begin{tabular}{|c|c|c|c|}
\hline 7 WB2 & $\begin{array}{l}\text { Use public research as a strategic resource } \\
\text { [2] }\end{array}$ & $\begin{array}{l}12 \\
\text { WW2 }\end{array}$ & $\begin{array}{l}\text { Use research exposure as a criterion for staff } \\
\text { appraisal [12] }\end{array}$ \\
\hline 9 WB3 & $\begin{array}{l}\text { Capacity building to access and use research } \\
\text { [12] }\end{array}$ & $\begin{array}{l}9 \\
\text { WW3 }\end{array}$ & $\begin{array}{l}\text { Combining in-house and external resources to } \\
\text { innovate processes [1] }\end{array}$ \\
\hline 10 WB4 & $\begin{array}{l}\text { Industry investments out of self-interest or to } \\
\text { respond to the demands of clients and } \\
\text { government policy [6] }\end{array}$ & $\begin{array}{l}7 \\
\text { WW4 }\end{array}$ & $\begin{array}{l}\text { Aim to maximize economic value through } \\
\text { intellectual property rights [5] }\end{array}$ \\
\hline 4 WB5 & $\begin{array}{l}\text { Development of R\&D supportive } \\
\text { procurement [3] }\end{array}$ & $\begin{array}{l}5 \\
\text { WW5 }\end{array}$ & $\begin{array}{l}\text { Ask project managers to identify and report on } \\
\text { innovation opportunities [20] }\end{array}$ \\
\hline 11 WB6 & $\begin{array}{l}\text { Move beyond the traditional practices to } \\
\text { adopt new practices [17] }\end{array}$ & $\begin{array}{l}3 \\
\text { WW6 }\end{array}$ & $\begin{array}{l}\text { Increase senior management awareness on benefits } \\
\text { of external knowledge to the budgets [20] }\end{array}$ \\
\hline 3 WB7 & $\begin{array}{l}\text { Include research exposure in job- } \\
\text { descriptions [12] }\end{array}$ & $\begin{array}{l}\mathbf{4} \\
\text { WW7 }\end{array}$ & Reward research-informed decision-making [12] \\
\hline 8 WB8 & $\begin{array}{l}\text { Increase the ability to attract, retain and } \\
\text { develop skilled people [18] }\end{array}$ & $\begin{array}{l}11 \\
\text { WW8 }\end{array}$ & $\begin{array}{l}\text { Organize events with employees returning from a } \\
\text { conference to share knowledge with other } \\
\text { employees [20] }\end{array}$ \\
\hline 1 WB9 & $\begin{array}{l}\text { Network with other/foreign industries to } \\
\text { collaborate in developing construction } \\
\text { management skills [19] }\end{array}$ & $\begin{array}{l}\mathbf{2} \\
\text { WW9 }\end{array}$ & $\begin{array}{l}\text { Develop a mechanism to identify important } \\
\text { innovative management practices [20] }\end{array}$ \\
\hline 6 WB10 & $\begin{array}{l}\text { Update knowledge of the workers on par } \\
\text { with the new knowledge generation [17] }\end{array}$ & $\begin{array}{l}\text { 1 } \\
\text { WW10 }\end{array}$ & $\begin{array}{l}\text { Offer chances to attend conferences as a reward for } \\
\text { deserved employees [20] }\end{array}$ \\
\hline $\begin{array}{l}5 \\
\text { WB11 }\end{array}$ & $\begin{array}{l}\text { Development of strategic and professional } \\
\text { leadership [12] }\end{array}$ & $\begin{array}{l}8 \\
\text { WW11 }\end{array}$ & $\begin{array}{l}\text { Share how knowledge contributions improved } \\
\text { performance creating an explicit cause-and-effect } \\
\text { link in organizations [5] }\end{array}$ \\
\hline & & $\begin{array}{l}\text { 10 } \\
\text { WW12 }\end{array}$ & Promote the concept of 'knowledge worker' [12] \\
\hline
\end{tabular}

Apart from the potential success factors applicable to individuals, there are potential success factors, which require collaborative implementation. Those factors include; Collaborate where the interests and values of each partner were articulated in advance and conflict of interest issues are resolved before legal and business arrangements established through a contract (Ellie, Andrew and Michael 2012), Give incentives to motivates staff and institutional leaders to participate or initiate R\&D (Bigelow, Bilbo and Baker 2016), Lead undergraduate research towards actual issues in the industry (Amaratunga and Senaratne 2009), Increase communication between researchers, research funders and research users, and Practice knowledge brokering (Alker 2008), Review how research can be effectively connected to real-world activity and policy setting; and Judged research programs not just by the quality and quantity of science produced, but by the industry impact and tangible benefits resulting from the research (Egbu 2004), Promote joint publications between university researchers, practitioners, and government; Enhance researcher-practitioner collaboration to research vital problems to find adoptable solutions; and Develop strategic partnerships (Meek et al. 2009), Embed researchers to companies as part of research activity (Puddicombe and Johnson 2011), and Collaborations and partnerships amongst governments, the economic sector, and research universities to link new knowledge to development goals (Kassel 2009).

Accordingly, the literature review delivered a sound set of potential success factors. Next, the factors were required to be located along the process of merging academic research and industry development requirements whilst paying attention to the actionable stakeholder roles. Therefore, a theoretical structure for bridging innovation to construction management practices is established in the next section. 


\section{Theories of Research-Informed Innovative Development}

Reviewing the theories on innovation, a specific historical situation labeled as Triple Helix Model (THM) describes a configuration, where state encompasses, and directs the relationships between academia and industry, who provide necessary knowledge infrastructure, wealth generation, and the political economy of innovative development (Etzkowitz \& Leydessdorff, 2000). THM is analytically different from the National Systems of Innovation Approach of Lundvall (2007), which considers the firm having the leading role in innovation, and from the "Triangle"' model of Sabato (1975), in which the state is privileged (Etzkowitz \& Leydesdorff 2000). THM of Etzkowitz and Leydesdorff (2000) has been accepted in various parts of the world as a successful model, for guiding innovation generation in different contexts; e.g THM application in China by Jun and Gui-sheng (2006); A case study based on International Cooperation for Innovation in the Dominican Republic by Villarreal and Calvo (2015); Institutionalising the Triple Helix in Sweden by Sandström (2000); A Triple Helix approach for brokering human and social capital in the UK by Papagiannidis, Etzkowitz and Clouser (2009), which complements THM over the promising results.

Research management in universities is a complex process, especially with the new challenges of expanding the research links with industry, commerce, government, and the community. For example, a study by Martin (2000) reveals the research management experience of managers from twelve higher education institutions in Europe, Africa, Asia, and Latin America related to the management of interfaces, financial and personnel management, and the management of the intellectual property. The case studies have demonstrated increasing relations with enterprises. To make the most of university-industry linkages, institutions tend to adopt more proactive and better-coordinated management approaches, while devising necessary rules and procedures to protect the traditional activities of higher education institutions from outside interference. Resembling most economic establishments and referring to the aforementioned discussions related to the available models, the research argues that the construction industry should try to attain some form of THM with the common objective of realizing an innovative environment consisting of strategic alliances among construction industry and academia. Whilst certain research (Villarreal \& Calvo 2015 ) hints on a few incapabilities of the THM in contextual applications, the very model has evolved into the Quadruple Helix and Quintuple helix stages addressing the contextual requirements. The newly added axes being society and natural environment (Carayannis, Barth \& Campbell, 2012) since THM focuses on the key players, it can be still justified as the best fit for the particular innovation considered here, which is at its very early stage at the moment.

Etzkowitz (2011) explains the integration of academia, industry, and government/regulatory bodies as a three-stage process. Firstly, the 'knowledge space' is identified with the emergence of regional innovation spaces, which will be occupied by different actors, who will improve local conditions for innovation through R\&D activities. Ideas and strategies for innovations will emerge through multiple reciprocal relationships between institutional sectors in a particular context, which has reached the 'consensus space'. In the 'innovation space', goals articulated in the previous phase will be realized equipped with capital, technical, and business knowledge, which are required for flourishing innovations (Etzkowitz, 2011). Accordingly, the academia, construction industry, and government/regulatory bodies can produce novelty, wealth, and legislative controls moving along the THM application. Interactions between academia and government/regulatory bodies can develop the dimension of knowledge 
infrastructure, while the construction industry and government/regulatory interactions can develop the necessary political economy. Consequently, the interactions between academia and industry will create innovations in construction management practice (Etzkowitz, 2011).

However, the creation of each space in the construction industry context will require specific changes to the practice of related stakeholders. Hence, it is vital to determine the critical requirements of the creation of each space at the stakeholder level. The requirements identified in the form of CSFs are highly user-friendly in implementation, as Rockart (1979) defined CSFs as "areas of activity that should receive constant and careful attention from management". Hence, the research was focused on developing a comprehensive set of CSFs for each stakeholder at different stages of the concerned process.

\section{Research method}

The empirical data were collected with a pragmatist philosophical stance, which is an integrated paradigm with a clear philosophical stand that lies in the middle of the quantitativequalitative paradigms continuum. According to Saunders, Lewis, and Thornhill, (2009), this philosophy facilitates solving a research problem irrespective of individual disadvantages of the approaches. Hence, a mixed-research approach comprising of surveys, case studies, and expert interviews (as necessitated by the research questions) were followed. Thereby, a fivestaged process was followed in developing CSFs as detailed in Table 3.

Table 3. The research process at a glance

\begin{tabular}{|c|c|c|c|c|c|}
\hline \multicolumn{6}{|l|}{ Stage 1 - Literature review } \\
\hline \multicolumn{2}{|c|}{ Outcome 1} & \multicolumn{3}{|c|}{ Outcome 2} & Outcome 3 \\
\hline \multicolumn{2}{|c|}{$\begin{array}{l}\text { i. Potential Success Factors for academia } \\
\text { a) Research initiation (11) b) Research execution } \\
\text { (09) } \\
\text { c) Research dissemination (07) }\end{array}$} & \multicolumn{3}{|c|}{$\begin{array}{l}\text { ii. Potential Success Factors for } \\
\text { industry } \\
\text { a) Industry level (11) } \\
\text { b) Organisation/practitioner level } \\
\text { (12) }\end{array}$} & $\begin{array}{l}\text { iii. Potential Success Factors to be } \\
\text { implemented in collaboartion (12) }\end{array}$ \\
\hline \multicolumn{6}{|l|}{ Stage 2-Surveys } \\
\hline Instrument 1 & \multicolumn{2}{|l|}{ Instrument 2} & \multicolumn{2}{|c|}{ Instrument 3} & Outcome \\
\hline $\begin{array}{l}\text { i. Academic Survey } \\
\text { Boundary: Entities from top- } \\
\text { ranked, state-funded Sri Lankan } \\
\text { universities, in the fields of } \\
\text { construction design, engineering, } \\
\text { and management } \\
\text { Unit: Academic researcher } \\
\text { Population: } 49 \text {, Sample:49 } \\
\text { (Census) } \\
\text { Response rate: } 69 \%\end{array}$ & \multicolumn{2}{|c|}{$\begin{array}{l}\text { ii (a). Industry Organisation } \\
\text { Survey } \\
\text { Boundary: Organisations in } \\
\text { top three local contractor } \\
\text { grades } \\
\text { Unit: An Organisation } \\
\text { Population: } 120 \\
\text { Sample: } 120 \text { (Census) } \\
\text { Response rate: } 25 \%\end{array}$} & \multicolumn{2}{|c|}{$\begin{array}{l}\text { ii (b). Industry } \\
\text { Practitioner Survey } \\
\text { Boundary: Chartered } \\
\text { qualified } \\
\text { professionals } \\
\text { Unit: A practitioner } \\
\text { Population: Unknown } \\
\text { Sample: } 390 \\
\text { Response rate: } 23 \%\end{array}$} & $\begin{array}{l}\text { Median, Validity and the Nature of the } \\
\text { relationship with the dependent } \\
\text { variable, 25th Percentile, } 75 \text { th } \\
\text { Percentile, Standard Error (within }+/-2 \\
\text { for the } 95 \% \text { confidence interval), } \\
\text { Regression Coefficient value, of the } \\
\text { factors subjected to two surveys were } \\
\text { calculated and used as the parameters } \\
\text { for ranking of factors in particular } \\
\text { categories }\end{array}$ \\
\hline \multicolumn{6}{|c|}{ Stage 3 - Expert interviews/Case studies } \\
\hline Instrument 1 & \multicolumn{4}{|c|}{ Instrument 2} & Outcome \\
\hline $\begin{array}{l}\text { i. Academic Research Expert } \\
\text { Interviews } \\
\text { - Research Experts from } \\
\text { Construction Management (AE1- } \\
\text { CM), Engineering (AE2-CE), and } \\
\text { Design (AE3-CD) }\end{array}$ & \multicolumn{4}{|c|}{$\begin{array}{l}\text { ii. Industry Case studies } \\
\text { - Three leading contractor organizations - selected } \\
\text { based on recent innovative moves, e.g. ERP } \\
\text { implementation } \\
\text { - Eight interviews with the senior management persons }\end{array}$} & $\begin{array}{l}\text { - Essential stages of innovation } \\
\text { - Stakeholders within essential } \\
\text { stages } \\
\text {-Stakeholder based CSFs }\end{array}$ \\
\hline \multicolumn{6}{|c|}{ Stage 4 - Development of the Model } \\
\hline \multicolumn{6}{|c|}{ Stage 5 - Model Validation: External validation } \\
\hline \multicolumn{4}{|c|}{ Instrument } & \multicolumn{2}{|l|}{ Outcome } \\
\hline \multicolumn{4}{|c|}{$\begin{array}{l}\text { Three high profile experts, who are extensively engaged in academic, industry, } \\
\text { and industry regulatory bodies reviewed draft the model }\end{array}$} & \multicolumn{2}{|c|}{$\begin{array}{l}\text { Proposed minor amendments were integrated and } \\
\text { the final model 'MRI' was formed }\end{array}$} \\
\hline
\end{tabular}


The potential success factors abstracted from the literature review (Stage 1) were subjected to an empirical screening through surveys with two populations, i.e. (i) academics with a construction management background, and (ii) construction industry organizations/practitioners in Stage II (Refer to Appendix 1 for excerpts). Larger sample sizes lower the likely error in generalizing to the population in line with the central limit theorem and law of large numbers (Saunders et al., 2009). However, Stutely (2003) advises on a minimum number of 30 from each category within the overall sample as a rule of thumb for statistical analyses, which was followed in this study due to the absence of large populations within the studied context. Moreover, censuses were conducted where the population sizes were too small due to contextual reasons such as lack of funds and researching opportunities. In terms of the data analysis, the statistical parameters considered for ranking the factors in the order of significance are given in Table 3 (Regression analysis dependent variables: academicindustry knowledge dissemination-utilization levels were obtained from the works of Hadiwattege et al., 2018).

The top-rated factors derived from Stage II analysis were inductively explored at Stage III. Expert interviews and case studies were conducted to collect data from academia and industry respectively. Interweevies were selected via judgemental sampling, from information-rich contexts related to the phenomena of interest as advised by Palinkas et al. (2015). The expert sample sizes were decided by data saturation. Excerpts from the interview guidelines are presented in Appendix I. For industry case studies, the critical case sampling was used as it allows to select cases based on the availability of necessary characteristics related to the studied problem (Saunders et al., 2009). The number of cases was decided at the data saturation. Respondents to the interviews were carefully selected considering; qualifications (Ph.D. for academic experts and Chartered with at least bachelor degree for industry case study respondents), experience (more than 10 years), and exposure (holding top-level positions in their respective organizations) to the studied phenomena. The collected qualitative data were subjected to content analysis on the within-case basis and cross-case basis. Concerning the data presentation, the phrases abstracted to the mind-map development are given with bold and italic effects. Discussion excerpts are provided at the relevant section using quotations from the interviews as examples of overall work.

The findings revealed the success factors leading to the formation of CSFs, which were fundamental to Stage IV in developing the model. Accordingly, the CSFs of creating knowledge space, consciences space, and innovation space separately regarding the actionable stakeholders; the university, the government/regulatory bodies, and the construction industry were identified. Finally, at Stage V, external validation was done via expert interviews (see Table 3) finalizing the development of the model, 'MRI'.

\section{Findings and Discussions}

\section{Findings from the Surveys}

At Stage II, academics evaluated the success factors of research at (i) initiation, (ii) execution, and (iii) dissemination. Whilst the industry samples evaluated the success factors, which can be implemented at the industry level and the individual organization/practitioner level. The factors were ranked in their respective categories based on the statistical analysis performed on 
the data sets. Table 4 presents the complete statistics of the academic survey concerning the research process related to potential success factors.

Table 4. Statistical Analysis-based Rankings of Success Factors for Research Initiation,

Execution and Dissemination for Academia

\begin{tabular}{|c|c|c|c|c|c|c|c|c|c|}
\hline \multicolumn{10}{|c|}{ Statistics - Success Factors for Research Initiation } \\
\hline \multirow[t]{2}{*}{ Rank } & 5 & \begin{tabular}{|l|l|}
4 & 8 \\
\end{tabular} & 10 & 11 & 6 & 1 & 2 & 7 & 3 \\
\hline & \begin{tabular}{l|l} 
WI1 & I \\
\end{tabular} & \begin{tabular}{|l|l|l} 
WI2 & WI? \\
\end{tabular} & WI4 & WI5 & \begin{tabular}{l|l} 
WI6 & W \\
\end{tabular} & \begin{tabular}{l|l} 
WI7 & WI8 \\
\end{tabular} & WI9 & WI10 & WI11 \\
\hline \multirow{2}{*}{$\begin{array}{ll}\text { N } & \text { Valid } \\
& \text { Missing }\end{array}$} & 30 & \begin{tabular}{l|l}
30 & 31
\end{tabular} & 30 & 30 & 30 & \begin{tabular}{l|l}
30 & 30
\end{tabular} & 30 & 30 & 30 \\
\hline & 0 & 0 & 0 & 0 & 0 & 0 & 0 & 0 & \\
\hline Median & 4.00 & $4.00 \quad 4.0$ & 4.00 & 4.00 & \begin{tabular}{l|l}
4.00 & 4.
\end{tabular} & 4.504 .00 & 4.00 & 4.00 & 4.00 \\
\hline \multirow[t]{2}{*}{ Percentiles } & 3.00 & \begin{tabular}{l|l}
3.75 & 3.0
\end{tabular} & 3.00 & 3.00 & \begin{tabular}{l|l}
4.00 & 4.
\end{tabular} & \begin{tabular}{l|l}
4.00 & 3.00
\end{tabular} & 4.00 & 3.00 & 3.75 \\
\hline & 4.00 & $4.00 \quad 4.0$ & 4.00 & 4.00 & \begin{tabular}{l|l}
4.00 & 4.
\end{tabular} & 4.50 & 4.00 & 4.00 & 4.00 \\
\hline 75 & 5.00 & \begin{tabular}{l|l}
5.00 & 5.0
\end{tabular} & 5.00 & 4.25 & 5.00 & 5.005 .00 & 5.00 & 5.00 & 5.00 \\
\hline Regression Co-efficient & .274 & $.237-.31$ & -856 & -.827 & -.850 & \begin{tabular}{l|l}
-1.331 & -.572
\end{tabular} & 3.742 & -.246 & 1.585 \\
\hline \multirow{2}{*}{$\begin{array}{l}\text { P-value } \\
\text { Std. Error }\end{array}$} & .570 & .004 & .052 & .107 & .143 & 029 & .002 & .620 & .004 \\
\hline & .483 & \begin{tabular}{l|l}
.098 & .33 \\
\end{tabular} & .440 & .513 & \begin{tabular}{l|l}
.581 & .6 \\
\end{tabular} & \begin{tabular}{l|l}
609 & .487 \\
\end{tabular} & .010 & .496 & .073 \\
\hline \multicolumn{10}{|c|}{$\begin{array}{l}\text { Statistics - Success Factors for Research Execution } \\
\end{array}$} \\
\hline \multirow[t]{2}{*}{ Rank } & 6 & \begin{tabular}{|l|l|}
5 \\
\end{tabular} & 4 & 8 & 7 & \begin{tabular}{l|l|}
9 \\
\end{tabular} & 1 & 3 & 2 \\
\hline & WP & WP2 & WP3 & WP4 & WP5 & WP6 & WP7 & WP8 & WP9 \\
\hline \multirow[t]{2}{*}{$\mathrm{N}$} & & 30 & 30 & 30 & 30 & 30 & 30 & 30 & 30 \\
\hline & & 0 & 0 & 0 & 0 & 0 & 0 & 0 & \\
\hline Median & 4.0 & 4.00 & 4.00 & 4.00 & 4.00 & 4.00 & 5.00 & 5.00 & 5.00 \\
\hline \multirow[t]{2}{*}{ Percentiles } & 4.0 & 4.00 & 4.00 & 3.00 & 3.75 & 3.00 & 4.00 & 4.00 & 4.00 \\
\hline & 4.0 & 4.00 & 4.00 & 4.00 & 4.0 & 4.00 & 5.00 & 5.00 & 5.00 \\
\hline 75 & 5.0 & 5.00 & 5.00 & 5.00 & 5.00 & 5.00 & 5.00 & 5.00 & 5.00 \\
\hline Regression Co-efficient & .05 & .088 & .585 & .238 & .182 & \begin{tabular}{l|l}
2 & -.114
\end{tabular} & .316 & -.780 & -.107 \\
\hline \multirow[t]{2}{*}{ P-value } & .00 & .046 & .006 & .566 & .66 & \begin{tabular}{l|l|}
7 & .780
\end{tabular} & .004 & .003 & .002 \\
\hline & .06 & \begin{tabular}{l|l}
61 & .056 \\
\end{tabular} & .071 & .414 & \begin{tabular}{l|l}
4 & .423 \\
\end{tabular} & \begin{tabular}{l|l|}
3 & .409 \\
\end{tabular} & .728 & .815 & .552 \\
\hline \multicolumn{10}{|c|}{ Statistics - Success Factors for Research Execution } \\
\hline \multirow{2}{*}{\multicolumn{3}{|c|}{ Rank }} & 7 & 4 & $\mathbf{3}$ & 1 & 6 & 2 & 5 \\
\hline & & & WD1 & WD2 & WD3 & WD4 & WD5 & WD6 & WD7 \\
\hline \multirow[t]{2}{*}{$\mathrm{N}$} & & Valid & 30 & 29 & 30 & 30 & 30 & 30 & 30 \\
\hline & & Missing & 0 & & 0 & 0 & & & \\
\hline \multirow{4}{*}{ Percentiles } & & & 4.00 & 4.00 & 4.00 & 5.00 & 4.00 & 4.00 & 4.00 \\
\hline & & 25 & 3.75 & 3.00 & 4.00 & 4.00 & 4.00 & 4.00 & 3.00 \\
\hline & & 50 & 4.00 & 4.00 & 4.00 & 5.00 & 4.00 & 4.00 & 4.00 \\
\hline & & 75 & 5.00 & 5.00 & 5.00 & 5.00 & 5.00 & 5.00 & 5.00 \\
\hline \multicolumn{3}{|c|}{ Regression Co-efficient } & -.159 & .134 & .706 & .527 & -1.312 & 1.108 & .131 \\
\hline \multicolumn{3}{|c|}{ P-value } & .771 & .745 & .001 & .046 & .071 & .038 & .724 \\
\hline \multicolumn{3}{|l|}{ Std. Error } & .548 & .411 & .503 & .559 & .726 & .535 & .371 \\
\hline
\end{tabular}

Accordingly, Median, Percentiles, and Regression Coefficients were used to rank the factors given the p-value and standard error proved the statistical validity of the data. Industry survey outputs were subjected to a similar statistical analysis process. Stage II, therefore, has delivered 
contextual rankings for the potential success factors abstracted from the literature (refer to Tables 1 and 2).

Progressively, the top-ranked factors in each sub-division of factor categories were taken forward to inductive approached Stage III analysis.

\section{Findings from the Expert Interviews and Case Studies}

Stage III dug further on context-sensitive factors (Stage II outcome) and the results are presented hereon.

Research experts' views on the top-ranked success factors of research knowledge dissemination

The research experts elaborated on the context-sensitive success factors resulted from Stage II relating to the main three stages of research; (i) initiation, (ii) execution, and (iii) dissemination. The information-rich discussions are summarised in the mind-map given in Figure 1.

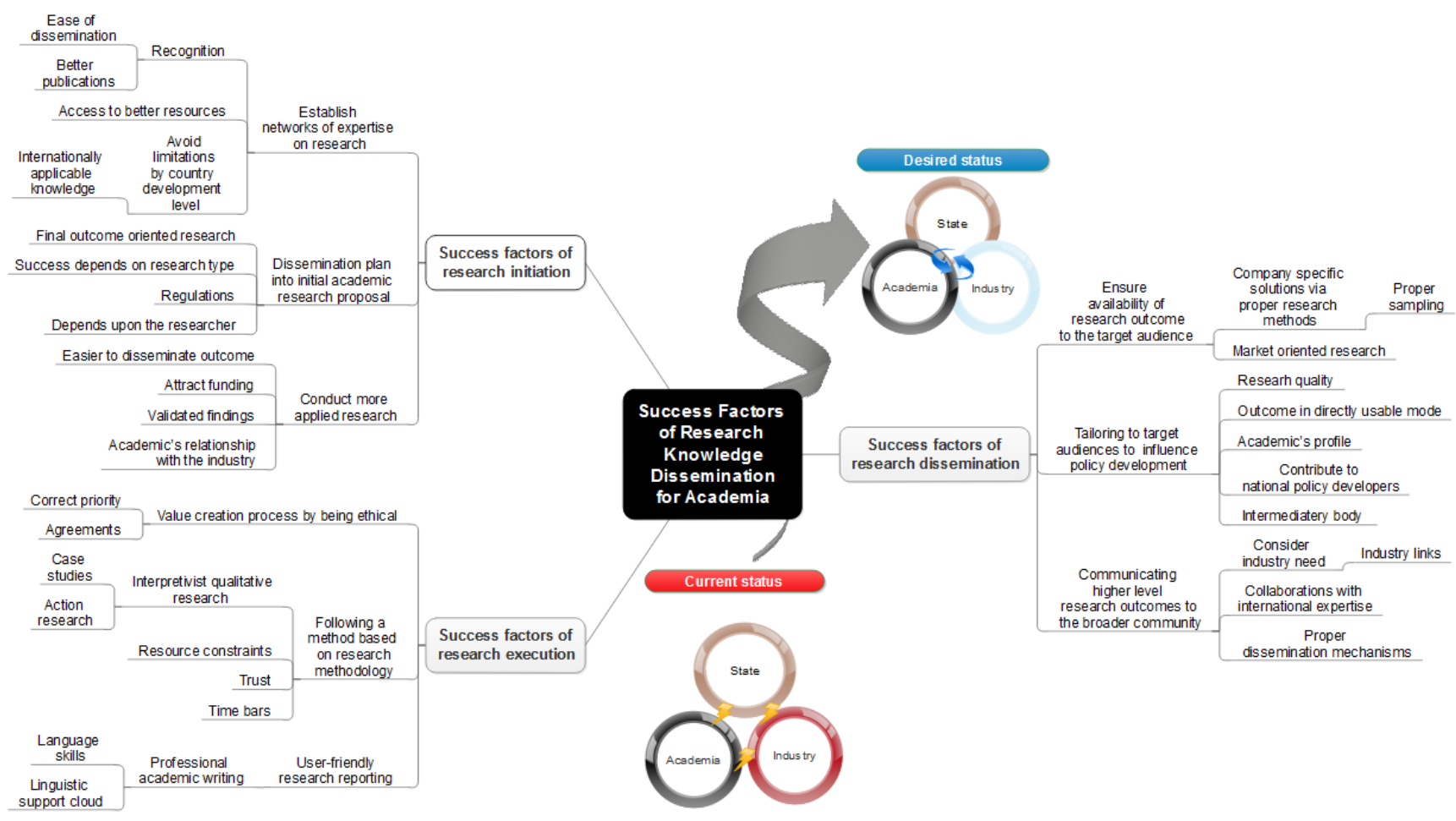

Figure 1. A mind-map summarising discussion on Success Factors for Academia

The research experts highlighted the benefits of networking since a network of expertise brings strong recognition to the research, researcher, and affiliation. AE1-CM stated that "high citation numbers can be achieved via such moves. It is good for the country and to the institution". The respondents also stated that dissemination is easier with a link to a network of expertise and better publications would be created. Importantly, AE1-CM and AE3-CD pointed out that such links can provide access to better resources for local researchers and avoid certain limitations. This kind of research would create knowledge, which is not limited by the level of development of the country, and display the global picture of the issue leading to accurate predictions and planning, generating internationally applicable knowledge. 
Similarly, details for the most influential factors identified in Stage II for other research stages were further explored as depicted in Figure 1. The discussions were mostly complementing the theories whilst highlighting contextual specifics supporting CSFs development.

Industry case respondents' views on the top-ranked Success factors for Research knowledge utilization

Three case studies (CS1, CS2, and CS3), each comprising multiple interviews [CSn-n(n=1-3)] provided the space to explore the context-sensitive factors derived from Stage II (Refer to Appendix I). The vivid information-rich outcome is summarised into a mind-map similar to Figure 1 of the discussions on both industry level and individual organization/practitioner level, which were useful in drafting the CSFs.

Extracting the facts elaborated in the discussions related to the organization/practitioner level: 'Serving opportunities for employees to be exposed to innovations', interviewees of all three cases mentioned the importance of training manager's service under which the employees are selected and sent to participate for seminars and similar knowledge disseminating arrangements. In case 03, the employees are encouraged to participate in short courses conducted by universities and professional bodies. Moreover, CS1-1 and CS2-2 stated that their organizations allocate funds for employees' research-related activities. The organizations' funds for higher studies, seminars, CPDs, short courses, and annual fees of the professional institution memberships for the employees. Further, the organizations grant leave for higher studies, seminars, and CPDs participation. Hence, the respondents suggest that the innovative companies provide employees exposure to innovation adoptions as confirmed by CS2-3's statement, "employees need to receive overall work experience, but should not be kept framed for a long time as it will fade the innovativeness of them". Further, all three cases claimed the importance of R\&D units.

In core, the discussions on industry level success factors revealed the current structural inferiorities of the industry to foster research-driven innovations and the lack of regulatory guidance on such at the industry level.

Research Experts' and Industry case respondents' views on Success factors to be implemented collaboratively

Both the academic research experts and industry cases were inquired on success factors of collaborations with academia. Hotspots appeared through discussions that were depicted in a mind-map similar to Figure 1, which were useful in drafting the CSFs.

Extracting the facts elaborated in the discussions with industry cases (showing the formatting arrangement used in developing the mind-map): In 'Promoting collaborations to link knowledge production to development goals, all three industry cases revealed that recessions lead to think of survival, therefore, the innovations become a less priority at such times and an economic boom to be maintained to foster innovations. Moreover, CS2-2 stated derecruitments may happen due to risks in recessions'. Further, case 01 and case 03 interviewees stated the need for developing a dialog between the industry, academia, and government over sustainable construction management development.

Discussions with research experts also made multiple value-additions, which were extracted through the content analysis in developing CSFs at Stage IV as discussed hereon. 


\section{Discussions on findings and Development of the Model of CSFs for Research-driven Innovations (MRI) for Construction Management}

Mostly, the context-sensitive success factors of research execution are related to 'ethics', 'methodology', and 'research reporting'. The results confirm the view of Saunders et al. (2009) on research ethics and of Le and Bronn (2007)'s, as the importance of research's methodological accuracy in contributing to value creation. About the research dissemination, findings confirm the need for ensuring the availability of the research outcome to the target audience as suggested by Ordoñez and Serrat (2009) though proper dissemination planning and execution. The necessity of a hub to manage academic-industry research interactions was repeatedly highlighted in the discussions with academia. Moreover, industry respondents stated their very busy schedules and resultantly the research efforts may fail in the long-run unless otherwise, an establishment is there to maintain the initiated relationships. Considering both parties' contribution to the discussion, knowledge brokering was pointed as key in academicindustry collaborations to examine and disseminate information and knowledge and to prepare usable, targeted synthesis for the clients, confirming the view of Alker (2008).

The first three stages of the research process established a sound basis to understand the critical gaps in the process of merging academic research and industry development requirements for construction management innovations. The qualitative data analysis firstly exposed the interrelationships between the factors, which was essential in deriving CSFs and to locate them within the developed model (refer Fig. 2). Secondly, Stage III up-lifted the short-listed factors to a new level by pointing out the exact gaps in the studied context. Finally, it was necessary to drill down to the exact CSFs for fostering research-driven innovations in the construction industry, which was achieved at the end of the external validation at Stage V. Accordingly, the developed CSFs were located along with the creation of the spaces against the actionable stakeholder as presented in the derived model (refer to Figure 2). 


\section{Novelty Production}

University

- $P$ rioritise research in academ ic job description

-Provide resources for research

- $P$ rovide administrative assistance to

KHB

- Include industry im pact into research

perform ance measurem ent criteria

-Standardise research via regulations

\section{Legislative Control}

Govenment/Regulatory Bodies

-Establish development goals for construction industry

- Include R\&D benchmarks into

contractor grading criteria

- Provide R\&D accreditations

- Practice research informed polic

development

- Ensure national research bodies functioning

Construction Industry

- Avoid research paradigm discrim ination - Manage change resistance

Switch from survival mode to

sustainable development mode

- Include research soundness into job

descriptions

Use research to avoid re-inventing the wheels at practice

Research Acaderia
- Maintain active relationships with the
industry
- Develop strong research profiles
- Develop time management skills
- Network with research comm unity
- Practice dissem ination as a habit

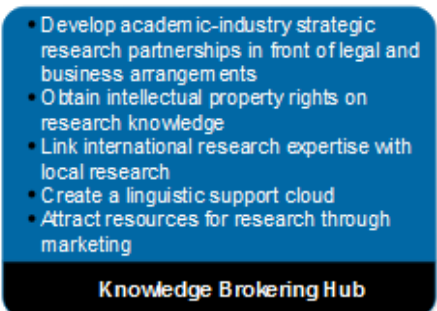

Industry O rgansiations

- Maintain active relationships with

academia

- Establish goals for innovative

development

- Establish R\&D units

- Create space for innovation investments

through proper company structure

- Develop professional approach to

- Develop professional appration managem ent

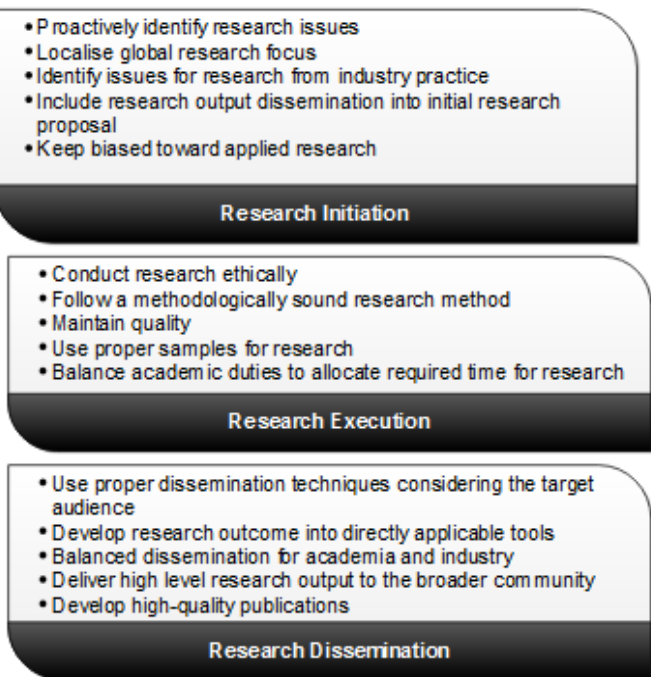

- Maintain open approach to innovation

- Support research with data

- Maintain a cooperative dynam ic staff

- Identify chances for gaining comparative advantage though innovations

- Acquire resources for innovations

Innovation Orientation

- Solve issues in practice with a scientific approach

- Conduct post analysis of projects

- Maintain accreditations

- Aim for award for the sector

- Network and follow successful innovations

Innovation Initiations

- Assure quality ofinnovations

- Train employees following adapted innovations

- Conduct feasibility studies prior innovation adoptions

- Reviewinnovation investments closely

- Evaluate options in selecting innovative solutions

Maintaing Innovations

Figure 2. Model of CSFs for Research-driven Innovations (MRI) for Construction

Management

In creating a knowledge space, it was identified that a dialog between academia, industry, and the government/regulatory bodies is fundamental (refer to Fig. 2). There are various possible CSFs to be operated by the three parties to create this dialog. Firstly, the government/regulatory bodies should play an active role in setting development goals for the construction sector. The construction industry should start solving issues in management practice with a scientific approach and invest in innovations. The university should provide the necessary guidance to 
measure the industry impact of research and place regulations as dissemination requirements to lead academic research towards industry collaborations. Therefore, the presented CSFs (refer to Fig. 2) will lead to creating a knowledge space, providing the base for the creation of a consensus space through the resultant knowledge infrastructure with the assistance from political economy.

In creating the consensus space, the missing knowledge infrastructure and political economy at present due to poor efforts from the universities, regulatory bodies, and construction industry should be eliminated through the establishment of a Knowledge Brokering Hub (KBH) (refer to Fig. 2). Hence, the external validation (Stage V) screened the final CSFs of creating a consensus space separately for academia, $\mathrm{KHB}$, and industry organizations.

The derived CSFs will create the consensus space leading to the creation of the innovation space by developing strategic research partnerships between academia and the industry organizations. The strategic partnerships will link researched knowledge to the innovationoriented industry organization needs, cultivating innovations in the construction management practice. Accordingly, KBH should generate strategic partnerships and formal alliances established based on agreements together with relevant legal and business arrangements. Under the guidance from $\mathrm{KBH}$, academic responsibility towards such collaborations will be provided within all three stages of research; initiation, execution, and dissemination. Similarly, with the guidance from $\mathrm{KBH}$, the industry organizations will adjust for innovation orientation, initiation, and maintenance. Ultimately, within the newly created innovation space, researchdriven innovative construction management will foster, where research will no more be an economic burden but a value addition.

\section{Conclusions}

This research investigated the CSFs of fostering research-driven innovations in construction management practice. The literature review proposed three major actors of industrial innovations. i.e. novelty producers, legislative controllers, and wealth generators, who are responsible for creating knowledge space, consensus space, and innovation space as explained in THM theory (Etzkowitz \& Leydesdorff, 2000). The three spaces of innovation generation were theorized by Etzkowitz (2011). Accordingly, CSFs were developed separately for each contender under each of the spaces based on the empirical screening of literature, and the Model of CSFs for Research-driven Innovations (MRI) was developed. MRI structures the CSF of enabling THM operation to foster research-driven innovations in the construction management practice.

Given that academia, industry, and the regulatory bodies adhere to the proposed CSFs in the knowledge space, the consensus space will be created. Within the consensus space, a KBH will be established to formalize the academic-industry research relationship along with the suggested CSFs application. The successful operation of this space will deliver researchinformed construction management innovation at the innovation space, whilst the CSFs of the same space will sustain the developed relationships. Hence, the developed model explains innovation integration as an essential three-staged process applicable to construction management. 
The study offered an evaluative perspective on an important economic sector's development requirements in the scope of a developing country environment. The study encountered a few limitations consequent to the methodological disadvantages, i.e. the findings rely on crosssectional data rather than longitudinal data, the data were collected from a single country, the data from the organization perspective were collected only from the contractor organizations rather than consultancy and client organizations, and, the data were collected only from the academic and industry perspectives due to the absence of a proper population to collect data on the government/regulatory body's perspective. However, the impact of the limitations was significantly irradicated by methodological advantages, i.e. use of mixed methods and triangulation techniques.

Finally, in terms of generalizability, the CSFs presented in the model 'MRI' (refer Fig. 2) apply to the studied context and beyond different construction contexts that are industry-lead, where weaker academic research lead management innovations present. Given, Sri Lanka's Human Development Index (HDI) in 2018 is 0.77 (UNDP, 2018), findings can be generalized to 'high human development' level countries. Moreover, the structure of the model 'MRI' can be applied to any construction industry along with the timeline, yet the CSF may need to be refined through external validation of the data. Besides, the basic theories related to pre-requisite spaces as per Etzkowitz (2011) and stakeholder roles as per Etzkowitz and Leydesdorff (2000) were integrated into the model and could be generalized irrespective of the industry. Yet, in applying to a particular industry, it would be necessary to localized parties playing each stakeholder role. Therefore, the objective of future studies shall be to validate the framework by applying it to real-world cases. Future research areas are directed on; 'exploring required policy changes for such a merge', 'sustainability of knowledge broking hubs in the built environment' and, 'necessities of shifting paradigms in management research for industry research collaborations'.

\section{References}

Alker, M. (2008). Guidance note on transferring research knowledge into action. Germany: German development institute.

Alwan, Z., Jones, P., \& Holgate, P. (2016). Strategic sustainable development in the UK construction industry, through the framework for strategic sustainable development, using building information modeling. Journal of Cleaner Production.

Amaratunga, D., \& Senaratne, S. (2009). Principles of integrating research into teaching in higher education: Built environment perspective. International Journal of Construction Education and Research, 5(3), pp.220-232.

Bigelow, B.F., Bilbo, D., \& Baker, M. (2016). Construction Management Research: A Comparison of Perceived Value by General Contractors, Prevalence of Publication, and Funding. International Journal of Construction Education and Research, 12(3), pp.224-240.

Bogers, M. (2011). The open innovation paradox: Knowledge sharing and protection in R\&D collaborations. European Journal of Innovation Management, 14(1), 93-117. 
Brandon, P. S., (2009). Seeking innovation: The construction enlightenment?. Technology, Design, and Process Innovation in the Built Environment, 528-543.

Brandon, P.S. (1982). Building cost research - the need for a paradigm shift?. In P.S. Brandon, ed. Building cost techniques: New Directions, London: E\&FN Spon, 5-13.

Brown, R. B. (2005). Why link personal research and teaching. Education + training, 47(6), 393-407.

Burgett, J.M., Smith, J.P., \& Lavang, Y. (2017). A Comparison between Industry's and Academia's Perceptions of a Career in Construction Education. International Journal of Construction Education and Research, 13(4), pp.251-266.

Carter, I. M. (2013). Changing institutional research strategies. Facet Publishing.

Egan, J. (1998). Rethinking construction. Report on the construction task force on the scope for improving the quality and efficiency of the UK construction industry. Department of the Environment, Transport and the Regions, London.

Carayannis, E.G., Barth, T.D., \& Campbell, D.F. (2012). The Quintuple Helix innovation model: global warming as a challenge and driver for innovation. Journal of Innovation Enterprise, 1 (2). retrieved from: https://doi.org/10.1186/2192-5372-1-2

Egan, J. (1998). Rethinking construction. Report on the construction task force on the scope for improving the quality and efficiency of the UK construction industry. Department of the Environment, Transport and the Regions, London.

Egbu, C.O. (2004). Managing knowledge and intellectual capital for improved organizational innovations in the construction industry: an examination of critical success factors. Engineering, Construction, and Architectural Management, 11(5), pp.301-315.

Ellie, T.R, Andrew, P., \& Michael, J.G. (2012). Toward Aligning Academic and Industry Understanding of Innovation in the Construction Industry. International Journal of Construction Education and Research, 8(4), 243-259

Etzkowitz, H. L. (2011). Working paper: The Triple Helix of University-Industry Government: Implications for Policy and Evaluation. Science Policy Institute, Stockholm.

Etzkowitz, H., \& Leydesdorff, L. (2000). The dynamics of innovation: From national systems and "Mode 2" to a Triple Helix of the university-industry-government relations, Research Policy, 29(2000), 109-123.

Fellows, R. (2010). New research paradigms in the built environment. Construction Innovation, 10(1), 5-13.

Fox, S.J. (2010). Information and Communication Design for Multi-Disciplinary MultiNational Education and Research. International Journal of Construction Education and Research, 6(1), pp.30-45. 
Godin, B., \& Gingras, Y. (2000). The place of universities in the system of knowledge production. Research Policy, 29(2), 273-278.

Hadiwattege, C., Senaratne, S., Sandanayake, Y., \& Fernando, N.G. (2018). Academic research in emerging knowledge-based economies: The case of Sri Lankan construction industry. Built Environment Project and Asset Management, 8(4), pp.415-428.

Hays, R. (2007). Research degrees for health professionals. Cornwall: T J and Digital.

Ivanova, I. A., \& Leydesdorff, L. (2014). Rotational symmetry and the transformation of innovation systems in a Triple Helix of the university-industry-government relations. Technological Forecasting and Social Change, 86, 143-156.

Jun, T., \& Gui-sheng, W. (2006). An introduction of the Triple Helix Model and its application in China. Science Research Management, 3(011).

Kassel, (2009). Higher education, research, and innovation: Changing dynamics. In V.L. Meek, U. Teichler, M.L. Kearney, eds. Report on the UNESCO forum on higher education, research, and knowledge 2001-2009.UNESCO.

Kulatunga, U., Amaratunga, D., \& Haigh, R.. (2005). Research and development, skills, requirements, and achieving excellence in construction. ARCOM Doctoral Workshop on Skills, Training, and Development in the Construction Industry.

Le^, M.A.T., \& Brønn, C. (2007). Linking experience and learning: Application to multiproject building environments. Engineering, Construction, and Architectural Management, $14(2), 150-163$.

Lundvall, B.Å. (2007). National innovation systems - analytical concept and development tool. Industry and Innovation, 14(1), pp.95-119.

MacLeod, I.A. (2010). The education of innovative engineers. Engineering, Construction, and Architectural Management, 17(1), pp.21-34.

Martin, M. (2000). Managing University-Industry Relations: A Study of Institutional Practices from 12 Different Countries. Improving the Managerial Effectiveness of Higher Education Institutions.

Meek, L. V., Teichler, U., \& Kearney, M. L. (2009). Higher education, research, and innovation changing dynamics: Report on the UNESCO forum on higher education research and knowledge, 2001-2009. International Centre for Higher Education Research Kassel (INCHER).

Noktehdan, M., Shahbazpour, M., Zare, M.R., \& Wilkinson, S. (2018). Innovation Management and Construction Phases in Infrastructure Projects. Journal of Construction Engineering and Management, 145(2).

OECD. (2010). Learning our lesson: Review of quality teaching in higher education. Institutional Management in Higher Education. 
Ordoñez, M., \& Serrat, O. (2009). Introduction to research and research method. UK: University of Bradford. Organization for Economic Co-operation and Development. (2010). Learning our lesson: Review of quality teaching in higher education. Retrieved from https://www.oecd.org/

Palinkas, L.A., Horwitz, S.M., Green, C.A., Wisdom, J.P., Duan, N., \& Hoagwood, K. (2015). Purposeful sampling for qualitative data collection and analysis in mixed method implementation research. Administration and Policy in Mental Health and Mental Health Services Research, 42(5), pp.533-544.

Papagiannidis, S., Li, F., Etzkowitz, H., \& Clouser, M. (2009). Entrepreneurial networks: A Triple Helix approach for brokering human and social capital. Journal of International Entrepreneurship, 7(3), pp.215-235.

Puddicombe, M.S., \& Johnson, B. (2011). Research and theory building in construction management. International Journal of Construction Education and Research, 7(2), pp.126142.

RD Direct. (2009). Research process flowchart, Retrieved from https://kcl.rl.talis.com/items/DAF73D81-82AA-5865-D962-06BD69156947.html Rockart, J.F. (1979). Chief executives define their data needs. Harward Business Review, 57(02), 81-93.

Rockart, J.F. (1979). Chief executives define their own data needs. Harward Business Review, 57(02), 81-93.

Sabato, J. A. (1975). Using Science to 'Manufacture' Technology. Impact of Science on Society, 25(1), 37-44.

Sandström, B.M. (2000). Institutionalizing the triple helix: research funding and norms in the academic system. Research Policy, 29(2), pp.291-301.

Saunders, M., Lewis, P., \& Thornhill, A. (2009). Research Methods for Business Students, (5th ed). Italy: Rotolito Lombarda.

Schiuma, G. (2012). Managing knowledge for business performance improvement. Journal of Knowledge Management, 16(4), 515-522.

Stutely, R. (2003). Numbers guide. Bloomberg Press.

United Nations Development Programme. (2018). Human development indices and indicators: 2018 Statistical update.

Villarreal, O., \& Calvo, N. (2015). From the Triple Helix model to the Global Open Innovation model: A case study based on international cooperation for innovation in the Dominican Republic. Journal of Engineering and Technology Management, 35, pp.71-92.

Ward, P.L. (2003). Continuous professional development and workplace learning 4: Conferences, wonderful conferences. Library Management, 24 (6/7), 367-369. 